\title{
Quality Implementation of Technical and Vocational Education and Entrepreneurial Skill Acquisition for Technology And Economic Development In Nigeria
}

\author{
Ikutal, Ajigo, Ph.D ${ }^{1}$, Edet, David Asuquo ${ }^{2,}$ Abeng, Christiana Oliver ${ }^{3}$ \\ $1,2 \& 3$ Department of Vocational Education \\ University of Calabar, Nigeria
}

\begin{abstract}
This study examined quality implementation of Technical and Vocational Education (TVE) and entrepreneurial skill acquisition for technology and economic development in Nigeria. It looked at standard of admissions policy, quality of personnel and standard of facilities. Three research hypotheses guided the study. Survey research design was adopted for the study. The population comprised heads of department, units' heads, senior non-academic staff, 300 and 200 levels students of 2016/2017 academic session from TVE department in two institutions. A sample of 135 respondents out of a population of 562 was drawn from University of Calabar (UNICAL) and Cross River University of Technology $(\mathrm{CRUTECH})$ for the study. Of this number, 125 representing $92.59 \%$ return rate was achieved. Census technique was used to select the staff, while purposive sampling was adopted in choosing 300 and 200 levels students in the 2016/2017 academic sessions. On the other hand, systematic sampling was adopted in selecting 300 and 200 levels students that actually responded to the instrument. A validated researchermade four point rating scale questionnaire captioned "Quality Implementation of Technical and Vocational Education and Entrepreneurial Skill Acquisition for Technology and Economic Development Questionnaire" (QITVEESATEDQ) was used for data collection. A reliability estimate of 0.71 was achieved for the instrument using Cronbach reliability coefficient after a pilot test was carried out. Data collected was analyzed using linear regression statistical tool and all hypotheses were tested at .05 significant level. Findings revealed that admissions policy, quality of personnel and standard of facilities in TVE departments significantly influence the acquisition of entrepreneurial skill for technology and economic development. It was therefore recommended among others that only merit should be the basis for granting admissions into TVE programs if it must lead to the acquisition of adequate entrepreneurial skill for technology and economic development.
\end{abstract}

Keywords: Vocational and technical education, quality implementation, entrepreneurial skill, acquisition, technology, economic development.

\section{Introduction}

Nigeria has over the years pride itself as the largest black nation in the world; the most populous nation in Africa; and the continent's giant. It is equally reputed with having enviable fundamentals including the $6^{\text {th }}$ largest gas reserve and the $8^{\text {th }}$ largest crude oil reserve in the world. The nation is endowed in commercial quantities with about 37 solid mineral types [18]. Yet, technological and economic development has been rather feeble and contrasting.
Compared with the emerging nations especially from the Asian continent, such as Indonesia, India, China, Malaysia and Thailand that were trailing behind Nigeria in terms of Gross Domestic Product (GDP) per capita as at 1970 [18]. These countries have advanced significantly and are not only miles ahead of Nigeria, but have emerged as major players on the global technological and economic development arena. These countries have undoubtedly harnessed the power of new technologies and nurtured droves of knowledge workers that are willing and able to propel the productivity and innovation tiers. Available literature tells that they have over the years made conscious efforts in the direction of investing, improving and enhancing the quality 
implementation of TVE programs in their respective countries which has led to myriads of impact including the acquisition of entrepreneurial skill, whereas, Nigeria played herself into the doldrums [9].

Globally, the two classical criteria most frequently adopted in assessing the state of wellbeing of countries are: the level of advancement in technology [13] and the pace of economic development [23], [3]. Essentially, these converging indicators remain the touchstones for which comparative ranking of countries hinges. According to [29], countries emerging in the first ten positions by rank order as technological giants in distinct areas with evidential solutions to the world's nagging challenges are: Japan, United States, Finland, South Korea, Germany, China, France, United Kingdom, Canada and Russia. Strides recorded by them which led to their attainment of this enviable height are in areas such as, but not limited to nuclear industry, aerospace, space technology, defense technology, IT, advance health innovations, exports, electrical, electronic and electromechanical fields, heavy duty equipment building as well as information and communication.

In appraising the state of economic development of countries for the year 2016, the International Monetary Fund (IMF) in her World Economic Outlook Database used the real Gross Domestic Product (GDP) growth rate [32] and the report revealed that Iraq, Turks and Caicos Islands as well as Nauru occupies the first, second and third positions with real GDP growth rate of 10.09 percent; 9.40 percent and 8.50 percent respectively. Nigeria with all her abundant resources occupies 193 positions with a GDP of 1.50 percent out of 218 countries surveyed, lagging behind African countries like Ethiopia which is ranked fourth with a real GDP growth rate of 7.96 percent; Cote d'Ivoire ranked seventh with a real GDP growth rate of 7.52 percent; Senegal and Tanzania in a tie rank of fourteenth and a real GDP growth rate of 6.60 percent each. Technology which is the application of scientific knowledge for the practical purposes, especially in industries involves the deployment of techniques, skills, methods, and processes necessary in the production of goods and services, or in the accomplishment of objectives.

Economic development, on the other hand is a construct most commonly used by politicians, economist, and others for so long a time now. It is a phenomenon that seeks to improve the economic well- being, quality of life and general improvement in living standards. It is typically associated with improvement in varied aspects such as: literacy level, life expectancy and the creation of wealth thresholds. But how did these countries found their niche among the "who-iswho' in the world? Quality implementation of technical and vocational education proves to be the propellant, and this when fittingly entrenched could result in entrepreneurial skill acquisition which is the antidote for combating rising youth unemployment- a significant cankerworm plaguing economies and societies [31]. In the words of [19], economic prosperity requires the possession of entrepreneurial skill to function optimally. The competencies of individual on entrepreneurial skill acquisition as it relates to TVE are thus, designed to lead the beneficiaries to self-employment, economic self-sufficiency, and increased employment generation, all of which constitutes the contributory factors for technology and economic development of a nation.

Entrepreneurial skill, therefore, was viewed by [15] as the ability to create something new with value by devoting the necessary time and effort, assuming the accompanying financial, physic, and social risks, and receiving the resulting rewards of monetary, personal satisfaction and independence. [25] termed it to be the ability of an individual to exploit an idea and create an enterprise (either big or small), not only for personal gain, but also for social and developmental gain. This can chiefly be attained through the acquisition and application of entrepreneurial skill. The process of acquiring this much desired skill according to [28], are in four stages namely:

1. To objectively analyze and identify the current and foreseeable skill needs in terms of management, administrative and technical skills. This calls for a critical assessment of the current and future state of the nation in the rung of technology and economic development ladder in relation to other well-to-do nations.

2. To identify the entrepreneurs own personal goals and objectives (in this case, TVE graduates) and accurately analyze as well as evaluate their own skills and resources attainment. This will help in examining the extent to which the quality implementation of 
TVE has been achieved, and if unsatisfied, define what else need to be done to bring about access to affordable quality TVE.

3. To provide a realistic personal (regional or national) development plan. For any advancement to be recorded in the direction of achieving technology and economic development through TVE, it will be apt to ensure that the plans proposed are realistic, timely, measurable and attainable.

4. To monitor the on-going performance of the entrepreneur once the pursuit has been launch. This requires appropriate periodic review of activities carried out with a view to consolidating areas of progress, while initiating improvement techniques in areas where progress seem retarded.

As a concept, TVE is described by the Federal Republic of Nigeria [12] as a comprehensive term referring to those aspects of the educational process involving in addition to general education, the study of technologies and related sciences, and the acquisition of practical skill, attitudes, understanding and knowledge relating to occupations in various sectors of the economic and social life. Overwhelmingly, the notion of 'quality' has overtime assumed one of the most sought-after attributes in almost every human endeavor, education inclusive. Perhaps this underscored why [27] voiced that quality in education may be viewed on the basis of how good and efficient the teachers are; how adequate and accessible the facilities and materials required for effective teaching and learning are; and how prepared the graduates are for meeting the challenges of life and for solving the social needs. [7] asserted that quality implementation of technical and vocational education is increasingly recognized as the bedrock of every development and an indispensable process for achieving national goals. These scholars went on to posit that continuous enhancement of the quality implementation of technical and vocational education remains the prerequisite for any nation that yearns to harvest the enormous benefits of this all-important aspect of education. Although at present TVE is perceived to be haphazardly implemented, a situation that has made attaining decent work an acute challenge; persistent of poverty in many part of the world including Nigeria, which counteract the impact-oriented and evidence-based nature of TVE; perception of graduates as ill-prepared for the world of work; and subjecting many to vulnerable employment [31], quality implementation of TVE begins with the formulation and adherence to admissions policy into the program at all levels.

The Joint Admission and Matriculations Board (JAMB) is the parastatal of the Federal Ministry of Education empowered by law to oversee matters of admission into tertiary institutions [22]. This it does by administering qualifying examinations to candidates [24]. Granting of admissions by this body is based on four cardinal factors. First is the quota system in which elements such as merit forms the criterion. This takes 45 percent of admission slots. Educationally disadvantaged state is the second factor which takes 20 percent. The third considerable factor is the catchment area, and is allotted 25 percent; the fourth which is the discretionary factor takes 10 percent [21]. It is worth stressing that when this policy was conceived, there were 25 federal, 13 states and 3 private universities in Nigeria as against the present 40 federal, 44 states and 68 privately owned universities [11].

[26], reported that with the quota system and catchment areas policies, universities are under obligation to admit students not entirely on merit, but on quota of states as stipulated by the government. This depicts a sheer compromise on quality, in that; merit is downplayed in preference for other sentimental considerations. [1] stated that the 2014/2015 admission lists of a state university revealed that while some local government areas had candidates scoring more than 200 points and above, others had only a handful of candidates who meandered to score up to 180 points which was the cut off marks. Those candidates who scored 200 and above and were from the so-called educationally advantaged local government areas where their quotas were already filled were denied admissions, whereas those candidates who scored 180 points from local government areas with less number of candidates were admitted. Since inputs determine the outputs, graduates from such compromised admission processes may hardly find their bearings in situations where Nigeria's technology and economic development quests could be helped.

Closely linked to the formulation and adherence to admissions policy is the issue of quality of personnel. Two-third of the workforce that constitutes the backbone steering the 
flagships in nations labeled 'economic and technological heavyweights' are employees who have garnered greater part of their occupational skills and knowledge through the support of quality teachers and instructors in the domain of technical and vocational education [10], [30]. In a study credited to [16] on ensuring quality assurance in vocational education, it was made known that the quality of teachers/trainers has very serious impact on the assessment of quality in the universities. The author stressed that quality cannot be guaranteed when the quality of personnel are inadequate to meet the desired expectations. This eloquently speaks of the TVE personnel qualifications, number, experiences, competences, capacities and their acquisition of desirable skills to relevantly impart their learners. Of a truth, no nation can rise above the quality of its teachers [12], and since knowledge is becoming truly global, accessible, and democratic, the unavoidable need for quality TVE personnel in the present stage of Nigeria's development is unmistakably keen especially as the nation aspires towards becoming a technological powerhouse.

To point the needed direction to all stakeholders, the [21] prescribed the minimum number and quality of personnel required in TVE departments. This covers the academic and nonacademic staff with a student-teacher ratio of 1:30. For the academic staff, the category stems from the Graduate Assistant cadre to the Professorial grade; with rank mixes and ratio of 20 percent in the professorial grade; 35 percent in the Senior Lecturer grade and 45 percent in the Lecturer 1 grade and below. For the nonacademic staff, the department running TVE and desirous of achieving and maintaining quality is expected to have at least one secretary (who must be computer literate), one clerical officer, two office attendants/cleaners, two typists, one laboratory attendants, and one technician. The impact of not meeting this minimum benchmark abounds. [2] decried that the continuous shortage of TVE experts is the bane of Nigeria's underdevelopment. [14] reiterated that serious shortfalls exist in the number of professionally qualified TVE teachers needed in the implementation of TVE program in schools.

Unfolding events lay bare the reality that the narrow and static paradigms of growth that sadly defines Nigeria amidst her natural resources endowments are directly associated with teaching TVE programs using crude, obsolete, malfunctioning, dilapidated and at times without facilities at all. The era when natural resources preponderantly made trade saleable are long gone, ushering in an era where this natural giftedness are convertible through the vehicle of quality facilities. According to Prosser in [8], effective training can only be given where the training jobs are carried out in the same way with machines as in the occupation itself. This implies that the exact machines, facilities, tools and equipment utilized in teaching TVE programs should not differ significantly from the ones the learners would meet and use in employment. Doing so would directly inhibit the transfer of knowledge to the world of work.

In a study, conducted by [17], it was concluded that inadequate training facilities form the major constraint to entrepreneurial skills development, which if properly articulated could help align the nation towards technological greatness. [7] when indirectly acknowledging that a nation's development agenda may be homegrown, advocate for the provision of adequate facilities, equipment, instructional materials and consumables, because they are objects with potency for enlisting Nigeria among the comity of nations laden with economic and technological prowess. The facilities required for effective teaching of TVE programs according to [21] include adequate classrooms, computer laboratories, internet access and resource room to ensure proper execution and implementation of programs. These facilities should not only exist, but be the best in terms of quality. Meaning that regardless of age, its continuous form or functionality should maintain originality in relation to when it was procured [6].

The absence of these facilities abound. [5] reports that during the 2006/2007 accreditation and admission exercises, NUC discovered gross inadequate availability of human (personnel) and non-human resources as well as dilapidated, decaying and almost non-available infrastructural facilities in most of Nigeria's universities. The accreditation exercise the scholar tell involved the assessment of 1,343 undergraduate degree programs (TVE program inclusive) in 48 universities comprising 25 federal, 20 states and three private universities with five colleges of education among. The memorandum released by the NUC further disclosed that 42.5 percent of the university programs earned full accreditation status, 40.9 percent earned interim accreditation while, 7.6 percent were out-rightly denied accreditation for failing to meet the prescribed 
minimum academic standard. The factors adopted in considering the type of accreditation were: quality of teaching, facilities, ratio of teachers to students, level of research contributions to international journals and number of foreign students among others [4].

Apparently, for Nigeria to speedily achieve vision 20:2020 and the Sustainable Development Goals (SGDs) which she is a signatory before the 2030 dateline, the nation ought to sail past the stop-start development patterns that hallmarks the present mono oil-based economy and lunch itself into the dawn of creating balance as well as a healthy base for the $21^{\text {st }}$ century society anchored on quality implementation of TVE. In pursuance of this benefit-laden course, can improvement in admissions policy, enhancement in the quality of personnel and the utilization of standard facilities in teaching TVE programs bring about entrepreneurial skill acquisition, and restore Nigeria to the path of technology and economic development? This forms the crux of the study.

\section{Purpose of the study}

The main purpose of the study was to examine the influence of quality implementation of TVE on entrepreneurial skill acquisition for technology and economic development in Nigeria. Specifically, the study:

1. Examine the influence of standard admission policy in TVE programs on entrepreneurial skill acquisition for technology and economic development.

2. Examine the influence of quality personnel in TVE departments on entrepreneurial skill acquisition for technology and economic development.

3. Examine the influence of standard facilities in TVE departments on entrepreneurial skill acquisition for technology and economic development.

\section{Research hypotheses}

The following hypotheses guided the study:

1. Implementation of admission policy into TVE programs has no significant influence on entrepreneurial skill acquisition for technology and economic development.

2. The quality of personnel in TVE departments has no significant influence on entrepreneurial skill acquisition for technology and economic development.

3. The standard of facilities in TVE departments has no significant influence on entrepreneurial skill acquisition for technology and economic development.

\section{Research methodology}

The study adopted survey research design involving the use of questionnaire in a bid to gather information on the quality implementation of TVE in Nigerian universities, and how it influences entrepreneurial skill acquisition for technology and economic development. Particularly, the focus was on admission policy, quality of personnel, and standard of facilities. Three research hypotheses guided the study. The study area was Cross River State, which is one of the 36 states in Nigeria. 135 respondents from the University of Calabar (UNICAL) and Cross River University of Technology (CRUTECH) were sampled from a population of 562. The sampling techniques adopted were census sampling for the heads of department, units heads and the senior non-academic staff; purposive sampling was adopted in choosing 300 and 200 level students in the 2016/2017 academic sessions because they were considered relatively exposed to the items contained in the questionnaire while systematic random sampling was adopted in selecting 300 and 200 levels students that actually responded to the questionnaire. This is shown in Table 1.

The structured questionnaire was validated by five experts, three in Vocational Education (Business Education, Agricultural Education and Home Economics) and two experts in measurement and evaluation. The reliability estimate of 0.71 was achieved for the instrument using Cronbach reliability coefficient after a pilot test. The instrument was administered personally by the researchers and retrieved after completion. This was done after relevant information about the problem being researched was explained to the respondents. A coding key was designed to code all responses. Of the one hundred and thirty five questionnaires distributed, one hundred and twenty five copies $(92.59 \%)$ were duly returned. Linear regression was used to test all the hypotheses at .05 level of significance. 


\section{TABLE 1}

Population and sample distribution of the study

\begin{tabular}{lllllll}
\hline Subjects & Population & \multicolumn{3}{c}{ Sample } \\
& UNICAL & CRUTECH & Total & UNICAL & CRUTECH & Total \\
\hline Head of departments & 1 & 1 & 2 & 1 & 1 & 2 \\
Units' heads & 3 & 3 & 6 & 3 & 3 & 6 \\
Senior non-academic staff & 10 & 12 & 22 & 10 & 12 & 22 \\
300 level students & 127 & 142 & 269 & 25 & 28 & 53 \\
200 level students & 132 & 131 & 263 & 26 & 26 & 52 \\
& & & 562 & & & 135 \\
\hline
\end{tabular}

\section{Results}

Hypothesis one

Implementation of admission policy into TVE programs has no significant influence on entrepreneurial skill acquisition for technology and economic development.

Test for significance was done using linear regression at .05 level of significance. A summary of the result is presented in Table 2 .

\section{TABLE 2}

Simple Linear Regression Analysis of implementation of admission policy into TVE programs on entrepreneurial skill acquisition for technology and economic development.

\begin{tabular}{|c|c|c|c|c|c|}
\hline Model & R Square & Adjusted R Square & Std. Error & Estimate & \\
\hline $.640^{\mathrm{a}}$ & .521 & .520 & & & \\
\hline Source of variation & SS & df & MS & F-ratio & $\mathrm{p}$-val \\
\hline Regression & 1242.380 & 1 & 1242.380 & $203.80 *$ & .028 \\
\hline Residual & 810.721 & 133 & 6.096 & & \\
\hline Total & $2,053.101$ & 134 & & & \\
\hline
\end{tabular}

$* \mathrm{p}<.05 ;$ df 1,$133 ;$ critical $\mathrm{F}=3.91$

From Table 2, the correlation between implementation of admission policy into TVE programs and entrepreneurial skill acquisition for technology and economic development was .640. This means that, as quality implementation of admission policy into TVE programs improves, so would entrepreneurial skill acquisition for technology and economic development improve. From the correlation coefficient, an R Square of .521 was obtained, this means that about $52.1 \%$ of the total variation in entrepreneurial skill acquisition for technology and economic development is accounted for by implementation of admission policy into TVE programs. The computed F-ratio of 203.80 is greater than the critical f-value of 3.91 with 1 and 133 degree of freedom. Also, the Table showed a p-value of .028 less than 0.05 level of significance. Consequently, the null hypothesis was rejected; this means that implementation of admission policy into TVE programs has significant influence on entrepreneurial skill acquisition for technology and economic development.

Hypothesis two

The quality of personnel in TVE departments has no significant influence on entrepreneurial skill acquisition for technology and economic development. 


\section{TABLE 3}

Simple Linear Regression Analysis of the quality of personnel in TVE departments on entrepreneurial skill acquisition for technology and economic development.

\begin{tabular}{|c|c|c|c|c|c|}
\hline Model & R Square & Adjusted R Square & \multicolumn{3}{|c|}{ Std. Error of the Estimate } \\
\hline $.582^{\mathrm{a}}$ & .498 & .497 & & & \\
\hline Source of variation & SS & df & MS & F-ratio & $\mathrm{p}-\mathrm{val}$ \\
\hline Regression & 1197.802 & 1 & 1197.802 & $178.38^{*}$ & .035 \\
\hline Residual & 893.055 & 133 & 6.715 & & \\
\hline Total & $2,090.857$ & 134 & & & \\
\hline
\end{tabular}

${ }^{*} \mathrm{p}<.05 ;$ df 1,$133 ;$ critical $\mathrm{F}=3.91$

From Table 3, the correlation between the quality of personnel in TVE departments and entrepreneurial skill acquisition for technology and economic development was .582. This means that, as the quality of personnel in TVE departments improve, so would entrepreneurial skill acquisition for technology and economic development improves. From the correlation coefficient, an R Square of .498 was obtained, this means that about $49.8 \%$ of the total variation in entrepreneurial skill acquisition for technology and economic development is accounted for by the quality of personnel in TVE departments. The computed F-ratio of 178.38 is greater than the critical f-value of 3.91 with 1 and 133 degree of freedom. Also, the Table showed a p-value of .035 less than 0.05 level of significance. Consequently, the null hypothesis was rejected; this means that the quality of personnel in TVE departments has significant influence on entrepreneurial skill acquisition for technology and economic development.

Hypothesis three

The standard of facilities in TVE departments has no significant influence on entrepreneurial skill acquisition for technology and economic development.

To test this hypothesis, independent t-test statistical technique was utilized. Test for significance was done using linear regression at .05 level of significance. A summary of the result is presented in Table 4 .

\section{TABLE 4}

Simple Linear Regression Analysis of the standard of facilities in TVE departments on entrepreneurial skill acquisition for technology and economic development.

\begin{tabular}{|c|c|c|c|c|c|}
\hline Model & R Square & Adjusted R Square & \multicolumn{2}{|c|}{ Std. Error of the Estimate } & \\
\hline $.810^{\mathrm{a}}$ & .785 & .783 & 1.2 & & \\
\hline Source of variation & SS & Df & MS & F-ratio & $\mathrm{p}$-va \\
\hline Regression & 1682.110 & 1 & 1242.380 & $208.75^{*}$ & .012 \\
\hline Residual & 791.564 & 133 & 6.096 & & \\
\hline Total & $2,473.674$ & 134 & & & \\
\hline
\end{tabular}

$* \mathrm{p}<.05 ;$ df 1,$133 ;$ critical $\mathrm{F}=3.91$

From Table 4, the correlation between the standard of facilities in TVE departments and entrepreneurial skill acquisition for technology and economic development was .810. This means 
that, as the quality of personnel in TVE departments improves, so entrepreneurial skill acquisition for technology and economic development improves. From the correlation coefficient, an R Square of .785 was obtained, this means that about $78.5 \%$ of the total variation in entrepreneurial skill acquisition for technology and economic development is accounted for by the standard of facilities in TVE departments. The computed F-ratio of 208.75 is greater than the critical f-value of 3.91 with 1 and 133 degree of freedom. Also, the Table showed a p-value of .012 less than 0.05 level of significance. Consequently, the null hypothesis was rejected; this means that the standard of facilities in TVE departments has significant influence on entrepreneurial skill acquisition for technology and economic development.

\section{Discussion of findings}

The result of hypothesis one revealed that the implementation of admission policy into TVE programs significantly influences entrepreneurial skill acquisition for technology and economic development. Of the four considerable factors upon which admission into TVE programs is based, merit system is viewed overriding with possibilities for entrepreneurial skill acquisition for technology and economic development. This finding corroborates [26] who found that using other bases outside merit such as quota system and catchment area policies, universities are obliged to admit students on grounds that clearly compromises quality and promotes mediocrity. This is worrisome in view of the fact that the quality of inputs determines the quality of outputs.

The result for hypothesis two revealed that quality of personnel in TVE departments significantly influences entrepreneurial skill acquisition for technology and economic development. This means that the [21] policy on numbers and quality as well as rank mixes and ratio of academic and non-academic staff in universities TVE departments if implemented to the later could launch the nation into technological and economic development stardom. This finding is in consonance with the [10],[31] who opined that two-third of the workforce that constitutes the backbone steering the flagships in nations labeled economic and technological heavyweights are employees who have garnered greater parts of their entrepreneurial skill and knowledge through the support of quality teachers and instructors in the domain of TVE. Accepting the dictum that no nation can rise above the quality of her teachers [12], and following it up with galvanized efforts towards recruiting the right caliber of personnel to run TVE programs in universities remains the lifeline.

The result in hypothesis three revealed that standard of facilities in TVE departments significantly influences entrepreneurial skill acquisition for technology and economic development. This implies that facilities in TVE departments in Nigerian universities are in a state of decay, moribund, obsolescence, and to a large extent non-existence. This makes the graduates of the program who would have been the drivers of technological and economic development agenda theory majors and practical minors, which contravene the creed of TVE. The finding is in sync with [5] who reported on the outcome of the 2006/2007 accreditation and admission exercises involving 25 federal, 20 states, and 3 private universities with 5 colleges of education inclusive. The finding as it were revealed gross inadequate availability of human (personnel), and nonhuman resources.

\section{Conclusion}

The crawling nature of Nigeria's technology and weakling economic development is not accidental; it is an accurate outcome of the many years of quality implementation of TVE neglect as revealed in the study. Formulation of lofty admissions policy, recruitment of adequate number of qualified personnel and investment in facilities in TVE departments in universities are merely on the pages of paper. The panacea for the nation's renaissance in technology and economic development is for the governments to put their money and actions where the put their mouth.

\section{Recommendations}

Based on the findings of the study, the following recommendations are made:

1. Only merit should be the basis for granting admissions into TVE programs in view of the fact that there is an equitable balance now in the establishment of universities across the nation, making the continuous adherence to other factors irrelevant.

2. A policy should be enacted by the government for an immediate recruitment of qualified personnel into TVE departments in universities. 
3. A pool in the name 'TVE facilities fund' should be established in all universities wherein contributions and donations from well- meaning individuals and corporate bodies are collected exclusively for the purpose of rehabilitating, development and procurement of the needed facilities for use in TVE departments.

\section{References}

1. Adayemi, K. (2001). Equity of Access and Catchment Area Factor in University Admission in Nigeria. Higher Education, 42, 307-332

2. Adegoke, K. A. (2002). Standard in Teacher Preparation in Nigeria: Some Highlights. Journal of Education for National Development (JOEND), 4(1\&2). Unique Educational Publishers, 1-6.

3. Anderson, G., Farcomeni, A., Pittau, M. G., Zelli, R. (2017). The wellbeing of nations: A multidimensional mixture distribution analysis of poor-nation-richnation status. IARIW-Bank of Korea Conference "Beyond GDP: experiences and challenges in the measurement of economic wellbeing, Seoul, Japan, April 26-28, 2017

4. Anho, J. E. (2011). An Evaluation of the Quality and Employability of Graduates of Nigeria Universities. African Journal of Social Sciences, 1 (1), 179-185

5. Anho, J.E. (2010). Human Resource Development of the Girl-Child in Overcoming Challenges in Nigeria as Third World Country in the $21^{\text {st }}$ Century .In Studies in Education, 11 (1), 231-245

6. Audu, R., I. Y. Umar, A.M. Idris (2013). Facilities provision and maintenance: Necessity for effective teaching and learning in Technical Vocational Education. Journal of Research and Method in Education, 3 (1), 28-32

7. Ayonmike, C. S., Okwelle, P. C. \& Okeke, B. C. (2015).Towards Quality Technical Vocational Education and Training (TVET) Programs in Nigeria: Challenges and Improvement strategies. Journal of Education and Learning, 4(1).

8. Ben, C. B. (2010). Vocational Education in Nigeria. Ibadan. El Summer Educational Books Nigeria Ltd.

9. Effoduh, J. C. (2015). The economic development of Nigeria from 1914 to
2014.Council on African Security and development.

10. European Centre for the Development of Vocational Training (CEDEFOP) (Ed.) (1998). Training for a changing Society: a report on current vocational education and training research in Europe. Thessaloniki: CEDEFOP

11. Fapohunda, O. (2017, February 2017). List of accredited/approved universities in Nigeria (updated)

12. Federal Republic of Nigeria (2004). National Policy on Education ( $4^{\text {th }}$ ed.), Lagos: National Educational Research and Development Council (NERDC) Press.

13. Florida, R. (2011). The World's Leading nations in innovation and technology. Retrieved on August 30, 2017 from https://www.citylab.com/life/2011/10/worl d-leading-nations-innovation-and technology/224/

14. Haruna, J. O \& Abbas, Z. S. (1996). Implementing the Vocational Technical Education Curriculum in Vocational/Technical Schools in Nigeria: Problems and Constraints. Nigeria Journal of Curriculum Instruction, 3 (2), 1-8

15. Hisrich, R. D. \& Peters, M. P. (2002). Entrepreneurship. Boston: McGrawHall/Irwin

16. Idialu, E. R. (2013). Ensuring Quality Assurance in Vocational Education. Contemporary Issues in Educational Research, 6 (4), 431-438

17. Ifeyinwa, M. C. \& Serumu, I. (2016). Constraints and remedy to quality vocational skills development among vocational education students in Nigeria as perceived by vocational educators. Journal of Innovative Practice in Vocational Technical Education, 1 (1), 16-23

18. Kekilume, M. (2015, December 12). Economic Development and Growth in Nigeria. Daily Trust. Retrieved on Saturday July 29, 2017 from https://www.dailytrust.com/news/saturdaycomments/economic-development-and growth-in nigeria/123963.html

19. Maigidi, J. F., Saba, T. M. \& Namkere, J. U. (2013). Entrepreneurial Skills in Technical and Vocational Education and Training as a strategic approach for achieving youth empowerment in Nigeria. 
International Journal of Humanities and social science, 3(5), 303-310

20. National Universities Commission (1999). Guidelines on University Admission. Abuja: NUC

21. National Universities Commission (NUC, 2007). Benchmark Minimum Academic Standards for Undergraduate Programs in Nigerian Universities, Abuja, Nigeria

22. Odigwe, F. \& Swem, F. (2016).Nigerian University Quota Admission System and Quality of Education in Universities in Cross River State, Nigeria. International Journal of Scientific Research in Education, 9 (4), 325-332. Retrieved on August $\quad 21^{\text {st }}, \quad 2017$ from http://www.ijsre.com

23. OECD (2017).Measuring wellbeing and progress: wellbeing research. Retrieved on September 1, 2017 from https://www.oecd.org/statistics/measuringwell-being-and-progress.htm.

24. Okoroma, N. S. (2008). Admission Policies and the Quality of University Education in Nigeria Educational Research Quarterly, 31 (3), 1-24

25. Olagunju, Y.A. (2004). Entrepreneurship Small Scale Business Enterprises Development in Nigeria. Ibadan University press Plc

26. Omeja, J. C. Egwa, E. I. \& Adikwu, U.O. (2016).Impact of Quota System and Cathment Area Policy on the University Admissions in North Central Nigeria. Sage open. Retrieved August 21 ${ }^{\text {st }}, 2017$ from http://journals.sagepub. 1-9

27. Oyabade, S. A. Oladipo, S. A. \& Adetoro, J. A. (2012).Determinants and Strategies for Quality Assurance in Nigeria University Education. Retrieved on August $30^{\text {th }}, 2017$ from http:www//.herp.net.org.

28. Pleshetter, L.A. (2009). Must have skills for entrepreneurs. https://www.powerhomebiz.com/00169/en treskills.htm 2009

29. The MeshNews (2016). Top 10 Countries with highest technology in the world 2017. Retrieved $7^{\text {th }}$ September, 2017 from https://www.themeshnews.com/top-10countries-with-highest-technology-in-theworld-2016
30. UNESCO-UNEVOC International Centre for Technical and Vocational Education and Training and UNESCO Institute for Statistics (2007). Participation in Formal Technical and Vocational Education and Training Programs Worldwide: an initial statistical study. Bonn: UNESCO

31. UNESCO (2016). Strategy for Technical and Vocational Education and Training (TVET) (2016-2021). France: UNESCO

32. Wikipedia (2017).List of Countries by GDP growth rate. Retrieved on September $3^{\text {rd }}$, 2017

from https://en.wikipedia.org/wiki/list_of_count ries_by realGDP_growthrate.

\section{Authors' Profile}

Dr. Ikutal, Ajigo had his first degree (B.Sc. [Ed.]) in Agricultural Education from the University of Calabar, Cross River State, Nigeria in 1994. He then proceeded to the University of Uyo, Akwa Ibom State, Nigeria where he bagged a Master's Degree and a Doctorate degree (M.Sc. [Ed.]) and Ph.D. all in Agricultural Education in 2005 and 2010 respectively. He started his lecturing career in 1996 with the Cross River State College of Education, Akamkpa as an Assistant Lecturer and rose to the rank of a Senior Lecturer. He held several positions including Head of Department and SubDean. In 2014, he transferred his services to the Department of Vocational Education, University of Calabar where he is currently lecturing. Dr. Ajigo is the incumbent departmental Graduate Board Chairman.

Edet, David Asuquo holds a National Diploma (ND) in Business Studies from the Polytechnic Calabar, Nigeria and a Bachelor's of Science Degree in Education (B. Sc. [Ed.]) in Business Education from Cross River University of Technology, Calabar, Nigeria. He is presently pursuing a Master's of Science Degree in Education (M.Sc. [Ed.]) in Business Education, in the Department of Vocational Education, University of Calabar, Nigeria. His area of specialty is Accounting Education. 
Abeng, Christiana Oliver is a holder of B.Sc (Ed.) degree in Business Education from the Cross River University of Technology, Calabar, Nigeria. She is currently a Master's degree student in the department of Vocational Education, University of Calabar, Nigeria. 